\title{
Characterization of a composite population of beef cattle in subtropical south Texas and the effect of genes for coat type and color on preweaning growth and influence of summer breeding on sex ratio
}

\author{
S. D. Lukefahr ${ }^{1}$ \\ Department of Animal, Rangeland, and Wildlife Sciences, Texas A\&M University-Kingsville, MSC 228, Kingsville
} 78363

\begin{abstract}
In the wake of global climate change, it is paramount that breeders use breed types with optimal performance ability. This investigation describes a unique 3-breed composite population of cattle in south Texas composed of Red Angus and tropically adapted Senepol and Tuli breeds. Under a low-input production system, trend analyses revealed that between 2005 and 2015 total direct costs per cow decreased by $\$ 180$ due largely to reduction of feed costs $(-9.40 \pm 4.3 \$ / \mathrm{yr} ; P<0.10)$. Despite years of serious drought, adopting increasingly conservative stocking rates, and decreasing mean weaning weights, profit per cow and per hectare were realized every year. Significant interaction existed between coat type of calf and color of calf and dam for weaning weight $(\mathrm{n}=183$ calves and 50 dams). For the light calf-light cow color cohort, slick compared with hairy coated calves differed by only $0.31 \pm 12.5$ $\operatorname{kg}(P>0.05)$. However, where either or both the calf and dam were red colored, a larger combined mean difference of $14.3 \pm 5.2 \mathrm{~kg}(P<0.05)$ favored slick over hairy calves. For preweaning traits, estimates of direct and maternal breed additive effects were obtained for all 3 breeds. Direct and maternal heterosis effects for birth weight were negligible (3.1 and 1.6\%, respectively). However, direct heterosis effects were more important for weaning weight and preweaning growth of $32.7 \mathrm{~kg}(12.5 \%)$ and $0.074 \mathrm{~kg} / \mathrm{d}$ (6.7\%), although the maternal heterosis effect on weaning weight was small $(1.4 \%)$. Chi-square analyses revealed $(P$ $<0.01)$ that about 1.5 times more bull than heifer calves were born $(\mathrm{n}=252)$ when conceived in summer. Overall, results of this experiment warrant further research.
\end{abstract}

\footnotetext{
The author declares no conflict of interest.

${ }^{1}$ Corresponding author: steven.lukefahr@tamuk.edu
}

Key words: beef cattle, crossbreeding parameters, preweaning growth, slick gene, sex ratio

\section{INTRODUCTION}

For well over a century, major breeding efforts have been made in the Gulf Coast region to introduce and evaluate potentially adaptable breeds or biological types of cattle that can cope with the subtropical climate, infestation by parasites, and periodic and severe droughts, among other challenges (Rhoad, 1955). These efforts have widely involved the application of crossbreeding. In more recent years, a plethora of papers have been published on aspects of sustainability (e.g., reducing carbon footprints and matching breeding and management practices with natural ecological phenomena). Moreover, in the wake of global climate change, it will likely become an even greater challenge to produce food to meet the demands of a rising human population (Nelson et al., 2009; Scasta et al., 2015; Ault et al., 2016; Davis et al., 2017).

A beef ranch located in south Texas has since 2005 been breeding for a more heat- and drought-tolerant type of cattle that involves a composite of Red Angus, Senepol, and Tuli breeds. The composite-bred cattle are mostly slick coated and light colored and are managed under a low-input production system involving sustainable management practices such as summer breeding and mid-spring calving, wintering calves on dams, stockpiling forage or rotational grazing (to avoid feeding hay), grassfed beef production, applying no chemical fertilizers to pastures, and using tropically adapted African genetics and available heterosis while selecting for moderate rather than extreme phenotypes with regard to optimal performance. Several of these practices are consistent with global efforts to mitigate the negative environmental impact of beef cattle production (Capper, 2011; FAO, 2013).

The research objectives were as follows: (1) to analyze trends involving costs versus profit per cow and per hectare; (2) to estimate the effects of coat type (slick vs. hairy) 
and color genes (light vs. red) on weaning weight; (3) to estimate direct and maternal breed additive and heterosis effects on preweaning growth traits; and (4) to test for distortion of sex ratio involving several years of maintaining a summer breeding program in south Texas.

\section{MATERIALS AND METHODS}

\section{Study Site and Environment}

The study was conducted on a privately owned ranch located in Kingsville, Texas, in the southernmost and subtropical region of Texas $\left(27^{\circ} 23^{\prime} 25^{\prime \prime} \mathrm{N}, 97^{\circ} 49^{\prime} 33^{\prime \prime} \mathrm{W}\right)$. Average precipitation for this region is approximately 55 $\mathrm{cm}$; however, since 1950 about 2 in every 5 yr have been marked by drought (Bryant, 2009). A herd consisting of approximately 50 cows grazed pastures on mostly sandy loam soils. Most land was leased, with total land area used for grazing ranging between approximately 135 and 200 ha in most years. Pastures largely consisted of exotic grasses, especially bermudagrass (Cynodon dactylon), guineagrass (Urochloa maxima), and Kleberg bluestem (Bothriochloa ischaemum), although several native species exist but were less abundant in terms of pasture composition. In good years, forage quantity can be as high as $5,000 \mathrm{~kg} /$ ha. Pastures were not chemically treated with fertilizers or herbicides for weed control, although encroachment of brush (e.g., Acacia farnesiana and Prosopis glandulosa) was controlled annually using herbicides via individual plant treatment.

In terms of pasture management, cattle were regularly rotated through pastures ranging in size from approximately 2 to 35 ha. Grazing as well as rest periods were usually between 3 wk and 3 mo, although grazing more than $50 \%$ of available forage was avoided. Stocking rate was generally about 1 animal unit per 4 ha, but in exceptional years of drought it was as low as 1 animal unit per 6.5 ha. In south Texas, most winters were mild without hard freezes, with green forage being available, eliminating the need for energy or protein supplements, although mineral and vitamin supplements were provided. In addition, hay has not been fed since 2001 due to the practice of stockpiling forage and maintaining low stocking rates. Additional details on forage management are reported by Ortega et al. (2013).

\section{Cattle Breeding Management and Breeds Used}

One pivotal management objective is to work closely with nature with calving occurring in mid-spring, mostly in May. This allowed cows to recoup their body condition by consuming early spring grass before calving, which emulates behaviors of wild large herbivores such as bison and deer. However, this decision necessitated a 45-d breeding season from mid-July through August (practiced since 2008). Historically, these 2 mo tend to have the least precipitation (between May and October) and the highest temperatures for the region (Nielsen-Gammon, 2011;
NOAA, 2017). Effects of heat stress negatively affect cattle fertility and embryonic survival in the Gulf Coast region (Hansen, 2013).

To address this and other environmental challenges, 2 tropically adapted, Bos taurus breeds-Senepol and Tuli-were introduced via AI and as natural service sires into the original commercial-based herd (e.g., Beefmaster and Santa Gertrudis crossbreds) between 2003 and 2004, as well as Red Angus. The Senepol and Tuli breeds were chosen based, in part, on reports from breeding studies conducted in the Gulf Coast region that showed favorable performances relative to other tropically adapted breeds and crossbreds (Chase et al., 1998; Hammond et al., 1998; Herring et al., 2005; Holloway et al., 2005; Phillips et al., 2005).

The Senepol breed was developed on St. Croix Island in the early 20th century and was developed from a foundation of N'Dama cattle from Senegal, West Africa. Of relevance to this study, Senepol cattle are red in color and possess a dominant gene for slick hair coats $(P R L R$ p.Leu $462 *$ mutation on chromosome 20; Littlejohn et al., 2014). In addition, Senepol display numerous vertical skin folds, especially in the neck region, which increase body surface area. Studies conducted in Florida by Hammond and Olson (1994) and Hammond et al. (1996) demonstrated that Senepol and Brahman purebreds had similar heat tolerance ability when measured during summer.

The Tuli breed originated from tropical southeast Africa. Tuli cattle possess red, white and dun genes for coat color. To briefly explain these genes, all Tulis are homozygous for the red gene [presumably $M C 1 R$ (melanocortin 1 receptor) as found in Red Angus] and of course have red coats (Lukefahr, 2007). At a separate locus, a dilution or white gene (pre-melanosomal protein deletion, PMEL) is found on chromosome 5, involves co-dominant expression, and based on the gene's base-pair sequence, appears to be the same allele as found in Galloway and Highland cattle (Davis et at., 2017). An animal without a white gene is red, with 1 white gene is yellow (due to co-dominance), and with 2 white genes is white. Hence, there is epistatic interaction between genes at these 2 loci. In contrast to red and white genes, the dun dilution gene (which appears to be recessive) is not always apparent at birth. Neonates that are yellow typically soon fade to light yellow or even almost white, seemingly depending on whether they possess 1 or 2 copies of the dun gene (Lukefahr, 2007). Schmutz and Dreger (2013) reported on a dun gene in Highland cattle that has similar semi-dominant expression, although the dun gene found in the Tuli breed has yet to be mapped and sequenced.

In the present study involving data collected from 2005 through $2015(\mathrm{n}=183)$, several sires and dams were heterozygous for coat type and color genes. To illustrate, slick $\times$ slick or slick $\times$ hairy matings could produce slick and hairy calves, and red $\times$ yellow matings produce red and yellow calves, and yellow $\times$ yellow matings produce red, yellow, and white calves. Red and yellow calves could be 
normal or lighter dun shaded. In several cases, some dams but mostly sires produced calves representing all 4 coatby-color subclasses. Data from cows and calves were separately grouped into 2 color classes: red or light (including dun, yellow, and white colors). Data were further sorted into coat type by color of calf-cow cohorts that yielded the following numbers: 13 slick-light-light (i.e., slick calf, light calf, light cow), 20 slick-light-red, 13 slick-red-light, 71 slick red-red, 6 hairy-light-light, 7 hairy-light-red, 11 hairy-red-light, and 42 hairy-red-red groups, respectively. The majority of the 50 dams had slick coats (66\%), and 5 dams $(10 \%)$ had very short hair coats due to some, albeit remote, Bos indicus ancestry. However, because there was an insufficient number of hairy dams, coat type classes of the dam could not be added to the above-described categories. Nonetheless, the heterogeneous nature of this population provided opportunities to assess the independent effects of coat type of the calf and color genes of both the calf and dam from that of breed composition.

Under experimental conditions it has been well demonstrated that lighter colors of coats in cattle reflect more solar radiation than darker coats (Bonsma, 1949; Finch et al., 1984). However, there is a paucity of published reports concerning potentially favorable effects of lighter colors on breeding cattle under pasture or range conditions. In published breed evaluation studies it is acknowledged that coat color is difficult to isolate as a factor and is confounded with the breed effect (Foster et al., 2009).

\section{Breeding Objective and Foundation of the Composite}

The breeding objective is to ultimately form a 3-breed composite of Senepol, Tuli and Red Angus breeds (the latter being presumed to be more heat tolerant than Black Angus), called STAR cattle, that would be adaptable and efficient under south Texas conditions. More specifically, this objective has focused on the breeding of moderatesized (approximately 450 to $500 \mathrm{~kg}$ ) and efficient cattle (cows weaning over $50 \%$ of their own BW) that readily breed in the summer; cows must produce a good calf consistently (weighing over $227 \mathrm{~kg}$ ), year after year, under a low-input management system. In addition, although there has been emphasis on selection for small calves at birth, there has been no selection pressure on increasing weaning weights.

Between 2003 and 2004, several purebred Senepol, Red Angus $\times$ Senepol, and Tuli $\times$ Red Angus heifers, and cows were purchased. In 2003 a purebred Senepol bull (a son of Nocona) and in 2008 a purebred Tuli bull (a son of Honey Bear) were leased for natural service. Further introductions, via AI, were made involving Red Angus, Senepol, and Tuli bulls. Initially as founders, several Red Angus bulls were used by AI that were descendants of Leachman's Eleanor; later a low-birth-weight Red Angus bull was purchased in 2012 from Pharo Cattle Company and used for 3 yr. A founder Senepol bull born in Texas (No- cona) was a popular AI sire in Australia, South America, and the United States. More recently, 2 low-birth-weight Senepol AI bulls: CN 4635 (Blondie) and WC 950K, both from St. Croix foundation herds, were used. A founder Tuli bull, Honey Bear, was a first-generation descendent of a representative sample of animals of the breed (J. E. Frisch, 2005, CSIRO, Rockhampton, Australia, personal communication) whose embryos were collected in Zimbabwe and exported to Australia in 1988. From Australia, Honey Bear was the first live Tuli bull exported to North America. Founder bulls were used over several years, mostly to produce more female replacements. For each year, the number of sires used (AI and natural) ranged from 1 to 5 bulls. Between 2005 and 2015, there were 6 Red Angus, 6 Senepol, 2 Tuli, and 6 three-breed composite bulls, representing a total of 20 sires. As previously stated, several AI founder sires, as well as purebred and composite bulls used in natural service, were used for multiple years.

The present population remains open to allow for the infusion of genes from outstanding specimens of these 3 breeds and until the population is adequately large to conserve genetic variability. Although technically the population is a 3-breed cross, in this paper it will be referred to as a composite because this is the ultimate goal. By 2005 the first 3-breed composite calves were born. For the next several years, a 3-breed rotational program was implemented to maximize potential heterosis while minimizing inbreeding. However, in more recent years mostly natural matings of rotationally crossbred bulls to rotationally crossbred cows were made to form the composite of near equal breed proportions and to simplify breeding management. Culling decisions mostly involved the selling of open cows and, during 1 yr of extreme drought, cows that were too large, made too much milk, or were over $50 \%$ Red Angus (being less adapted based on poorer body condition).

\section{Traits Measured and Calf Management}

Production traits measured included cow pregnancy and calf weaning survival rates, total production versus total feed costs per cow, and profit per cow (calf market value minus total cow cost) and kilograms in weaned calves per hectare, as well as stocking rate. Calf BW were recorded at approximately 6 to $7 \mathrm{mo}$, and local auction prices were obtained to represent market value. Between 2005 and 2012, calves were weaned at approximately 6 to 7 mo of age using the fence-line weaning method. From 2012 through 2015, calves were wintered on dams to 10 mo of age (but were still weighed at approximately 6 to $7 \mathrm{mo}$ ), mostly to further minimize weaning stress, decrease calf feed and labor costs during winter, and so on. Calves were vaccinated using 7-way clostridial and 4-way respiratory modified-live or killed virus (infectious bovine rhinotracheitis, bovine respiratory syncytial virus, bovine viral diarrhea, and parainfluenza-3) vaccines. Breeding animals received the same vaccinations annually at approximately 2 to 3 mo before calving; bulls only received the 4 -way vaccination. 
Birth weights were preadjusted for age of dam effects, and weaning weights were preadjusted to a 205-d basis, as well as for age of dam effects using additive values as recommended by the Red Angus Association of America (RAAA, 2013). Furthermore, weaning weights were preadjusted to a steer basis using multipliers of 1.15, 1.0, and 0.95 for heifers, steers, and bulls, respectively (BIF, 2010).

\section{Statistical Analyses}

For production traits, line plots using linear regression procedures were conducted and tested using the Student's $t$-test to assess trends from 2005 to 2015 . For the analysis of weaning weight involving the coat type and color objective, data were sorted from records that included calves produced by sires, dams, or both with ancestry from Red Angus, Senepol, Tuli, or a combination of any of the 3. Some calves and dams had earlier ancestry from other breeds represented in the original herd. Criteria used in data editing for subsequent analyses were that sires had to be either purebred Red Angus, Senepol, and Tuli or a composite of all 3 breeds. Dams had to inherit genes from at least 1 of these 3 breeds. Furthermore, either the sire or dam of each calf had to have Senepol ancestry and be slick coated. These criteria resulted in the elimination of 286 records. The final data set consisted of records from 183 calves from 20 sires and 50 dams. Means (ranges) for breed proportions for calves were 0.339 (0 to 0.813 ) for Red Angus, 0.305 (0 to 0.750) for Senepol, 0.277 (0 to 0.750) for Tuli, and 0.079 (0 to 0.375$)$ for other breeds, and for dams were 0.311 (0 to 0.688) for Red Angus, 0.352 (0 to 1.0) for Senepol, 0.191 (0 to 0.563) for Tuli, and 0.144 (0 to 0.50) for other breeds. Means (ranges) for direct and maternal heterozygosity proportions for calves and dams were 0.780 (0.375 to 1.0) and 0.891 (0 to 1.0), respectively.

The statistical model for weaning weight records included the random effect of animals and fixed effects of yearpasture (contemporary groups; $\mathrm{n}=14$ ), the combined slick by coat color of calf by dam subclasses (to test for 2and 3-way interactions between coat type of calf and color of calf and dam via linear contrasts), a linear covariate associated with direct heterozygosity level of the calf, and random error. Data were subjected to mixed-model procedures employing MTDFREML (Boldman et al., 1993). This full animal model included additive genetic relationships for all calves, their parents, and other relatives with records born since 2005. In addition, several collateral relatives of each breed(s) were added to the pedigree file to add additional relationships to deepen genetic ties among related purebred sires and their crossbred progeny (including those used subsequently as sires and dams) across years to augment the mixed-model equations for a total of 235 animals involved in subsequent analyses. Further, several purebred and 3-breed composite sires were halfsiblings and sire-sons, which likewise strengthened genetic ties across years of the study.
The rationale for using a full animal model that accounted for genetic relationships was an attempt to separate genetic effects of coat type and color genes from total additive genetic effects (breeding value) of animals, breeds, or both for weaning weight. This approach was a critical aspect of the experimental design in minimizing confounding between these genetic factors as well as the year-location (contemporary groups) environmental source, bearing in mind that the slick gene originated from Senepol base animals, whereas light color genes originated predominantly from Tuli base animals. In running the analysis, a heritability of 0.37 for weaning weight was first estimated using an iterative procedure of MTDFREML, which was needed to obtain solutions for all mixed-model equations. (It was not an experimental objective to estimate heritability.) It was assumed that additive genetic variances were the same for all breeds, as well as the extent of the nonadditive genetic effect of direct heterosis involving all breed combinations on weaning weight performance.

To address the next objective of estimating crossbreeding parameters (e.g., direct and maternal breed additive and direct and maternal heterosis) for preweaning traits (birth and weaning weights and preweaning gains), a subset of the aforementioned data set (including 2016 data) involved animals $(\mathrm{n}=116)$ that were entirely of Red Angus, Senepol, and Tuli ancestry. The model consisted of the random effect of animals (including genetic relationships), the fixed effects of contemporary group (yearpasture), and linear covariates associated with the breed additive composition of the calf and dam and direct and maternal heterozygosity level of the calf and dam, and random residual error. Direct heterozygosity level of the calf and dam were calculated as one minus the sum of the products of the respective breed proportions shared between the calf's or dam's sire and dam (Bourdon, 2000). Regression of growth trait values on heterozygosity levels of calves or dams was performed to compute direct and maternal heterosis in the same model. It was assumed that a linear relationship exists between levels of heterozygosity and heterosis.

In running the analysis for preweaning traits, an iterative procedure of MTDFREML was first conducted to obtain heritabilities for birth weight $(0.32 \pm 0.17)$, weaning weight $(0.37 \pm 0.18)$, and preweaning gains $(0.35 \pm 0.19)$, which in turn were applied to obtain solutions for mixedmodel equations. The present heritability value for birth weight of 0.32 is lower than the value of 0.43 , whereas the heritability value for weaning weight of 0.37 is similar to the value of 0.36 (averaged by sex of calf) that are used by International Genetic Solutions in multibreed genetic evaluations of cattle less than 50\% Simmental (including Red Angus) (Lauren Hyde, 2017, lead geneticist, International Genetic Solutions, Bozeman, MT, personal communication). For this analysis, it was again assumed that additive genetic variances were the same for all 3 breeds for each 
trait, as well as the extent of the nonadditive genetic effect of heterosis involving different breed combinations.

To solve linear equations for covariates involving breed additive effects, it was first necessary to determine the breed composition for all calves and dams (calculated as proportions from pedigree data). However, because the breed additive composition of a calf or dam summed to one, an analysis involving covariates for all 3 breeds would result in a singular matrix without solutions. Therefore, a restriction was imposed whereby for each calf or dam the additive breed proportion of Senepol and Tuli was expressed as a deviation from the proportion of Red Angus (serving as the control breed). Equations for Red Angus proportions were then excluded from the analyses. Solutions for both Senepol and Tuli breeds as partial regression coefficients (direct or maternal breed additive) were then summed to provide estimates for Red Angus. Leastsquares means for each breed were calculated by adding to the overall mean the sum of both direct and maternal breed additive genetic solutions. Percentage direct heterosis was calculated by taking the heterosis estimate, divided by the combined least squares means of the 3 breeds, times 100 .

However, the MTDFREML program does not provide SEM for fixed effects (including heterosis estimates), although SE of the mean difference can be computed using linear contrasts. From 3 separate analyses, the Senepol and Tuli breed proportions of the calf and dam were deviated from Red Angus in the first analysis, then the Red Angus and Tuli breed proportions from Senepol in the second analysis, and next the Red Angus and Senepol breed proportions from Tuli in the last analysis. To obtain SE of the difference, contrasts for the direct and maternal breed additive coefficients were fitted between the 2 breeds in the model. The SE were then averaged across all 3 analyses for each breed additive coefficient for each trait to provide pooled SE of the difference values.

As previously stated, the ranch practices summer breeding mid-July through August. Between 2008 and 2016 there was a rather consistent observed pattern of the birth of more bull than heifer calves. This trend was first noted between 2008 and 2010, but it was decided that more years of data would be needed to test the hypothesis of equal sex ratio. For the sex ratio analysis, records of all calves born between 2008 and 2016 that resulted from summer matings were used $(\mathrm{n}=252)$. A supplemental data set involved $4 \mathrm{yr}$ when a fall calving herd $(\mathrm{n}=34$ calves) was also managed, which was used to compare sex of calf results to those from summer breeding. The hypothesis was tested that higher temperatures-favoring the fertilization of eggs by Y-bearing sperm cells - altered sex frequencies from the a priori probability of 0.5. However, it was appropriate to first test whether or not sex ratio was consistent across years, which was conducted using Chi-square procedures (SAS Institute Inc., Cary, NC). If this analysis yielded nonsignificant results, then it would be appropriate to directly test the hypothesis of a 1:1 sex ratio.

\section{RESULTS AND DISCUSSION}

\section{Production Trait Trends}

Presented in Figures 1 and 2 are trend plots for production traits that project costs and profits. These plots largely reflect the joint effects of genetic (performance, adaptability, or both) of the composite population and environmental management for a low-input production system, and in some cases market prices. For basis of comparison, common benchmark values can be used for mean weaning weight of $227 \mathrm{~kg}$ (500 pounds), stocking rates of 4.05 or 8.09 ha (10 or 20 acres) per cow, and annual profit of $\$ 100$ per cow. Although not included as figures, from 2005 through 2015 mean pregnancy and weaning rates were 97.0 and $99.3 \%$ (range of 89.7 to $100 \%$ and 93.8 to $100 \%$, respectively). Of relevance, the majority of matings were by natural service. In addition, assistance needed at calving was negligible for all years. For both fertility and survival, the mode was $100 \%$ with no apparent trend across years.

For total annual direct costs per cow, the linear regression coefficient $(-4.58 \pm 5.5 \$ / \mathrm{cow})$ was not significant because it was highly variable, being largely driven by feed and temporary lease costs in years of drought (Figure 1). Total cow production costs averaged $\$ 352$ across all years and was at $\$ 276$ by 2015 . However, 2005 and 2015 were not drought years, and the reduction in total production costs was $-\$ 180$ per cow. This difference was mostly due to reduced feed costs (at a linear rate of $-9.40 \pm 4.3 \$ / \mathrm{yr}$; $P<0.10$ ), which was largely achieved, in part, by more appropriate pasture management (e.g., adjusting stocking rates and stockpiling forage). In more recent years, only a limited amount of cottonseed cubes was fed (cost of $\$ 0.57 / \mathrm{kg}$ in 2015 ), mostly to call up cattle. The relatively high feed cost of $\$ 185$ in 2009 occurred during an extreme drought year when whole cottonseed was fed to breeding animals for several months.

For annual profit per cow, the linear trend $(65.1 \pm 18.0$ $\$$ (cow; $P<0.01$ ) shows an increase in profits over year. However, market prices were unusually high between 2013 and 2015. By replotting the linear function between 2005 and 2012, it was evident that profits were still achieved at an increasing rate $(24.6 \pm 15.7 \$ /$ cow; $P<0.05)$. Because market prices consistently increased over the same time period, prices were averaged over 5 yr before 2013 and applied to 205-d adjusted weaning weights to redetermine market value. Results revealed that a linear trend no longer existed for profit per cow $(-1.37 \pm 6.10 ; P>$ 0.05 ), even though a profit was actually made every year. In 2016 it was projected by the USDA (2016) that total cash costs would average about $\$ 851$ per cow and that calf returns would be only $\$ 86$ per cow. Producers would need to better manage their production costs.

After coping with years of drought, management gradually adopted more conservative stocking rates $(0.429 \pm$ 0.10 ha/animal unit; $P<0.001$ ), which was approximately 5 ha/animal unit by 2015 (Figure 2). (The typical lease 
cost was $\$ 44.48 /$ ha per year.) As expected, this decision reduced BW in weaned calves yielded per hectare $(-9.05$ $\pm 1.92 \mathrm{~kg} / \mathrm{ha} ; P<0.01)$. Further, between 2005 and 2015, mean 205-d adjusted weaning weights decreased ( -5.51 $\pm 2.26 \mathrm{~kg} / \mathrm{yr} ; P<0.10$ ) from 283 to $260 \mathrm{~kg}$, possibly in response to breeding management placing continued selective emphasis on sires with low birth weight EPD and animals with moderate mature BW. During the same period, mean BW of cull cows in good body condition was $525 \pm$ $22 \mathrm{~kg}$. Despite negative effects of drought, reductions of herd stocking rates and decreased calf weaning weights, profit per hectare was maintained across years $(0.909 \pm$ $0.60 \$ /$ ha; $P>0.05)$. However, replotting the linear function from 2005 through 2012 (ignoring the unusually high market prices between 2013 and 2015) yielded results of $0.674 \pm 0.66 \$ /$ ha $(P>0.05)$.

\section{Effects of Coat Type and Color of Calf and Dam on Weaning Weight Performance}

Analyses revealed that significant 3-way interaction existed between type and color of coats of calves and dams
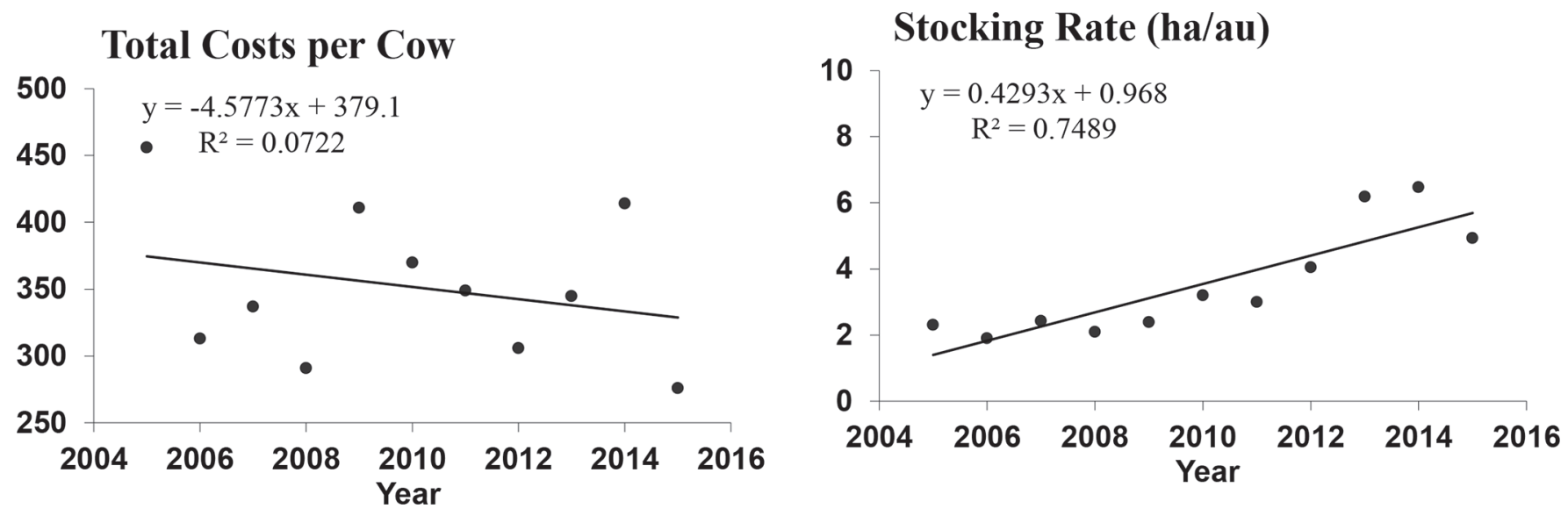

\section{Feed Costs per Cow}
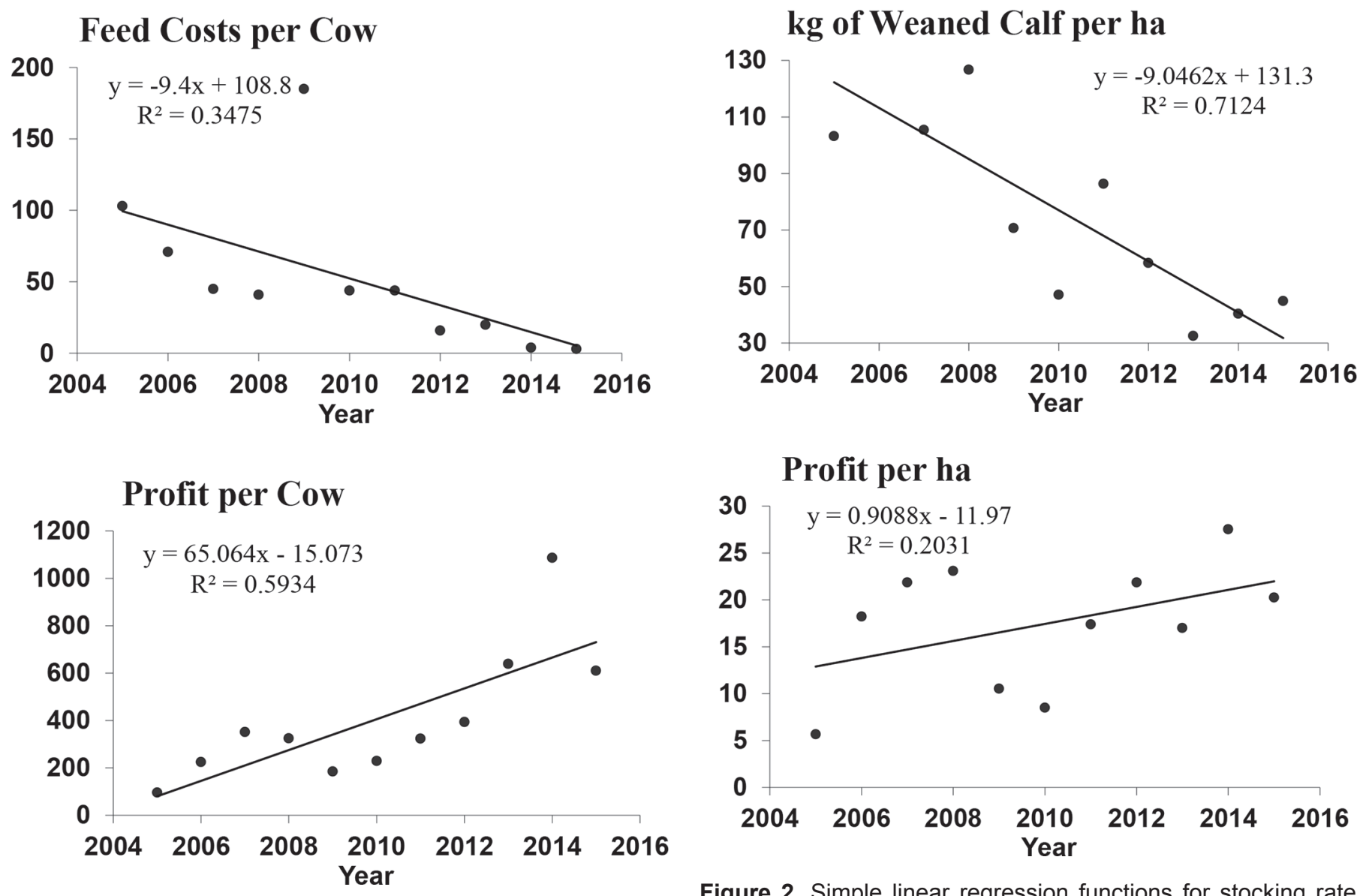

Figure 1. Simple linear regression functions for total-production and total-feed costs and profit per cow (\$) from 2005 to 2015.

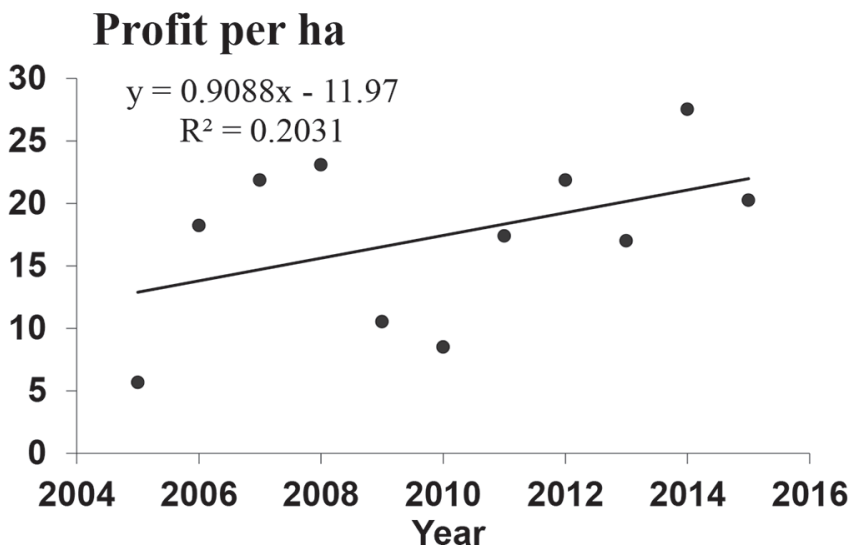

Figure 2. Simple linear regression functions for stocking rate (au = animal unit) and total kilograms weaned and profit (\$) per hectare from 2005 to 2015. 
on weaning weight, which was quantified through use of linear contrast comparisons. In other words, the effect of the slick gene depended on the color of the calf-dam cohort or vice versa. Therefore, it was not appropriate to either perform tests for or make general conclusions about the effects of slick and color genes on weaning weight performance. Instead, linear contrast comparisons of coat type by color subclass means were conducted. The nature of the interaction is illustrated in Figure 3, where it is illustrated that slick compared with hairy calves tended to be heavier when either or both the calf or dam was red in color.

For the light calf-light cow cohort, slick compared with hairy calves had similar mean weaning weight values (difference of only $0.31 \pm 12.5 \mathrm{~kg} ; P>0.05$ ). A plausible explanation is that a light calf, whether slick or hairy, remained longer with its yellow dam during daytime grazing, rather than preferring shade. (To reiterate, most cows in the study were slick and presumably were heat tolerant.) However, the sample was small $(\mathrm{n}=13$ slick and 6 hairy calves), so this result is questionable. Further research is warranted to test this proposed hypothesis that would require the taking of grazing time measurements.

For the other cohorts where either or both the calf or cow was red, the linear contrast mean difference of 14.3 $\pm 5.2 \mathrm{~kg}(P<0.05)$ was observed between slick and hairy calves. Specifically, mean differences involving linear contrasts of slick versus hairy calves for light calf-red cow, red calf-light cow, and red calf-red cow cohorts were as follows: $13.5 \pm 10.4(P>0.05 ; \mathrm{n}=20$ and 7$), 17.3 \pm 10.5$ $(P>0.05 ; \mathrm{n}=13$ and 10$)$, and $12.1 \pm 4.8 \mathrm{~kg}(P<0.01$; $\mathrm{n}=71$ and 43 ), respectively. It is hypothesized that hairy calves of these 3 cohorts preferred shade over prolonged daytime grazing due to a lower physiological threshold for heat tolerance, which subsequently affected preweaning growth; this hypothesis also needs to be formally tested

However, for slick calves numerically similar weaning weights were observed between light calf-light cow and the red calf-red cow cohorts ( 280.3 and $283.2 \mathrm{~kg}$ ), suggesting that hair coat type may be more important than color. Finch et al. (1984) documented that so long as the hair coat is short enough for more reflection (as opposed to absorption) of solar radiation to occur, the animal may exhibit some level of heat tolerance. By combining cohort least-squares means, slick coated-red colored calves were $14.8 \pm 5.7 \mathrm{~kg}(P<0.05)$ heavier than hairy-red calves. In contrast, slick and light colored calves appeared to be less favorably affected, showing a smaller difference of 6.9 $\pm 8.1 \mathrm{~kg}(P>0.05)$ compared with hairy coated-light colored calves. These comparisons suggest that these color genes may still impart an effect, albeit minor, relative to the slick gene, in terms of heat tolerance.

Under summer conditions in subtropical Florida, Olson et al. (2003) demonstrated that slick versus hairy Senepol crossbred calves had significantly lower rectal temperatures and respiration rates, although the difference between these groups on weaning weights was not significant and was confounded by other genetic factors. In the same region, Hammond and Olson (1994) reported negative correlations between rectal temperature and total grazing time across Angus, Brahman, Hereford, and Senepol breed types. However, Littlejohn et al. (2014) reported the heat tolerance ability extended beyond the mere role of a short hair coat. It was demonstrated that although no differences were observed in sweat gland histology between slick and control animals, a role between circulating prolactin and increased sweating rates was implicated.

In a grazing experiment from Australia involving Brahman Hereford-Shorthorn crossbred steers, Finch et al. (1984) reported that lighter-colored animals spent more time in open sunlight and grazing than darker-colored steers, presumably due to higher heat loads for which darker animals could not counterbalance physiologically. In contrast, in a South African study, Peters et al. (1982) reported no benefits of coat color (ranging from light gray to black) in terms of weaning weight of Afrikander crossbred calves. In one feedlot study involving Bos taurus crossbred steers, Mader et al. (2002) observed that darker compared with lighter colored steers expressed more excessive panting and bunching behaviors and had higher tympanic temperatures. However, breed types and pedigrees of the cattle were unknown, so these results for coat color may have been confounded with other genetic factors. An ideal experiment would involve numerous sires that are heterozygous for slick and color genes that are randomly

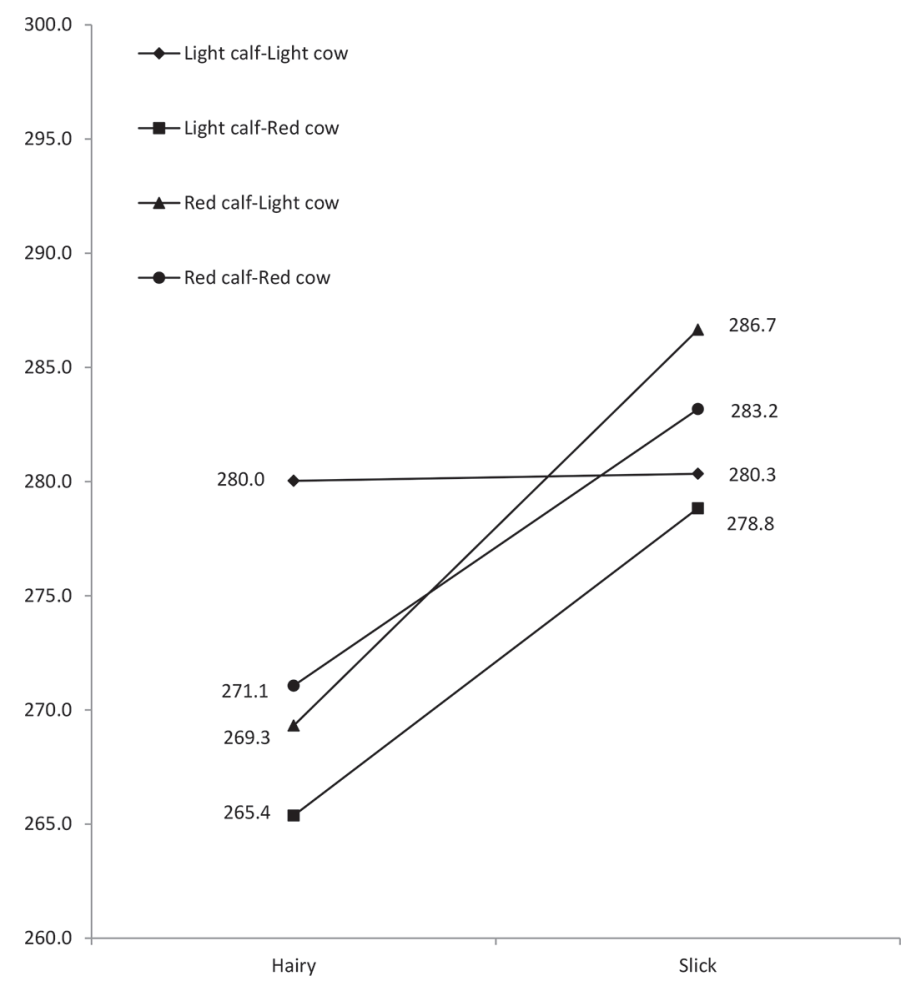

Figure 3. Line plots of least-squares means for weaning weight (205-d adjusted; $\mathrm{kg}$ ) for hairy and slick coated calves by calfdam body coat color cohort (Light $=$ light dun, yellow, or white). 
mated to heterozygous, or more preferably homozygous recessive cows, and whose progeny as calves and as mature breeding animals are measured for many relevant traits.

\section{Estimates of Crossbreeding Parameters on Preweaning Growth}

It must first be clearly stated that estimates of crossbreeding parameters were used primarily to genetically characterize the composite population, and to a lesser extent to statistically evaluate breeds. The composite was formed to represent particular lines and even specific animals within each breed. Further, crossbreeding parameters portray the genetic architecture of the composite breed population in terms of the independent quantitative effects of genes (breeding value) and retained heterosis for the traits examined. In 2016, the mean breed proportions of calves were $34.8 \%$ Red Angus, $24.3 \%$ Senepol, 36.6\% Tuli, and $4.2 \%$ other. In addition, the mean inbreeding coefficient for calves born in 2016 was $5.3 \pm 0.68 \%$ (range of 0.40 to $14.6 \%$ ). In Figure 4, photos are presented of a Star composite cow and a yearling bull from the 2016 calf crop.

Estimates of crossbreeding parameters for preweaning growth traits are presented in Table 1. For birth weight, Tuli showed the largest negative direct breed additive value of $-3.71 \mathrm{~kg}$ compared with the $5.00-\mathrm{kg}$ value of Senepol, which approached significance $(P<0.10)$. Consistent with present results, Herring et al. (2005) reported from 2 research station locations (Brooksville, FL, and Uvalde, TX) a combined contrast estimate for mean birth weight of Tuli- versus Senepol-sired calves of $-2.5 \mathrm{~kg}$, which estimates one-half the direct breed additive value or betweenbreed EPD. For the maternal breed additive effect, Senepol differed $(P<0.05)$ from Tuli $(-2.66$ vs. $2.92 \mathrm{~kg})$, and Red Angus was intermediate. Interestingly, Senepol had a positive direct breed additive value and a negative maternal breed additive value, whereas Tuli showed the opposite pattern. Red Angus was intermediate for both parameter estimates with values being negative. Chase et al. (2004) reported lighter birth weights of Angus-sired calves of 28.5 versus $32.1 \mathrm{~kg}$ from immature $\mathrm{F}_{1}$ cows sired by Tuli compared with Senepol, and lighter birth weights of Charolais-sired calves of 35.9 and $38.4 \mathrm{~kg}$ from mature (3- to 8-yr-old) $\mathrm{F}_{1}$ cows sired by Tuli compared with Senepol. Holloway et al. (2005) likewise reported lighter birth weights in Hereford-sired calves of 33.2 versus 35.9 $\mathrm{kg}$ from immature $\mathrm{F}_{1}$ cows sired by Tuli compared with Senepol. However, in these cited studies, the mean difference between $\mathrm{F}_{1}$ dams reflects a joint contribution of both direct and maternal breed additive effects.

Direct and maternal heterosis values for birth weight were small (3.1 and 1.6\%). In agreement, Chase et al. (1998) reported 3.5\% direct heterosis for birth weight in $\mathrm{F}_{1}$ Senepol $\times$ Hereford crossbred calves in subtropical Florida. These values are consistent with the general estimate of $2.4 \%$ direct heterosis from literature reports for Bos taurus crossbred calves and $1.8 \%$ for Bos taurus crossbred dams as reviewed by Weaber (2015).

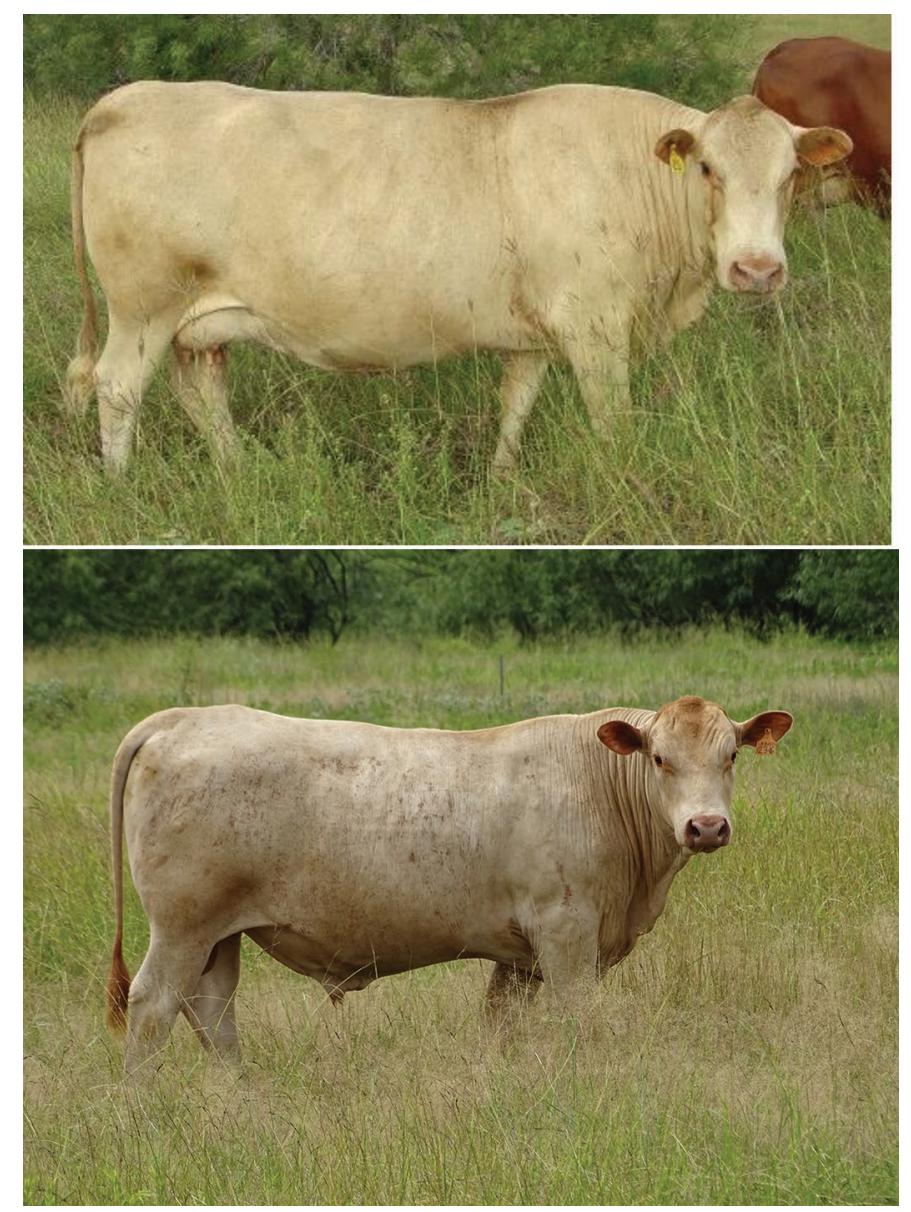

Figure 4. Composite cow and yearling bull of Red Angus, Senepol, and Tuli breeding, exemplifying slick and light-colored coats while bearing many other genes for tropical adaptation. Color version available online.

For weaning weight and preweaning gains, statistical differences for crossbreeding parameters were never significant (Table 1). Results for preweaning gains closely paralleled those of weaning weight with respect to breed rank, sign of direct and maternal breed additive values, or both. The overall weaning weight mean of $261.4 \mathrm{~kg}$ for the composite population is well above the benchmark value of $227 \mathrm{~kg}$ for low-input systems involving moderate-sized and typically purebred cows. It would appear that Tuli had the most favorable influence toward genes for growth (direct breed additive value of $11.4 \mathrm{~kg}$ ), followed by Red Angus (value of $4.3 \mathrm{~kg}$ ), whereas Senepol imparted a negative contribution (value of $-15.7 \mathrm{~kg}$ ). In contrast, between 2 breeding experiments, Herring et al. (2005) reported a -2.1-kg difference in mean weaning weight of Tuli- versus Senepol-sired calves, which varies from one-half the difference (EPD) between Tuli and Senepol of $13.8 \mathrm{~kg}$ in the present study. An explanation for this dissimilarity is that founder animals during the initial formation of the composite population were not sampled randomly from their respective breeds.

For Red Angus and Senepol breeds, the sign for maternal breed additive effects was opposite that of the direct 
breed additive effects, while Tuli had positive values for both parameters. Senepol had the higher and positive maternal breed additive value of $11.6 \mathrm{~kg}$, which was similar to the direct breed additive value of Tuli. Chase et al. (1998) also reported a higher maternal breed additive value for Senepol compared with Herefords, indicating greater milking ability. Chase et al. (2004) and Holloway et al. (2005) reported no statistical differences in mean weaning weights in calves reared by mature $\mathrm{F}_{1}$ cows sired by Tuli compared with Senepol; however, as previously stated it is not possible to discern between the joint contributions of direct from the maternal breed additive effects from their estimates.

Direct heterosis for both weaning weight and preweaning gains were large, being $32.7 \mathrm{~kg}(12.5 \%)$ and $0.074 \mathrm{~kg} / \mathrm{d}$ $(6.7 \%)$, respectively. The $32.7-\mathrm{kg}$ direct heterosis figure for weaning weight is closer to values reported from Louisiana (Franke et al., 2005) of $35.6 \mathrm{~kg}$ for Bos taurus by Bos indicus crossbreds compared with general literature values of $7.4 \mathrm{~kg}$ for Bos taurus crossbreds (Weaber, 2015). In addition, maternal heterosis was estimated at $3.7 \mathrm{~kg}(1.4 \%)$, being much smaller than the estimate for direct heterosis. This value is within the range of $1.5 \mathrm{~kg}$ for Bos taurus by Bos indicus crossbred dams (Franke et al., 2005) and 8.2 $\mathrm{kg}$ for Bos taurus crossbred dams (Weaber, 2015).
In a supplemental analysis, direct heritabilities for birth and weaning weights of 0.43 and 0.36 and maternal heritability for weaning weight of 0.19 [used by International Genetic Solutions in multibreed genetic evaluations of cattle less 50\% Simmental (including Red Angus); Lauren Hyde, 2017, lead geneticist, International Genetic Solutions, Bozeman, MT, personal communication] were used to re-estimate crossbreeding parameters. For birth weight, parameter solutions were very similar between the 2 analyses. For weaning weight, there were no changes in breed rank, the estimates for direct heterosis were similar (32.0 vs. $32.7 \mathrm{~kg}$ ), but the estimates for maternal heterosis differed ( 8.9 vs. $3.7 \mathrm{~kg})$.

\section{Sex Ratio Analyses}

Space does not permit a show of figures for weather statistics for each year, so these were averaged across the $9 \mathrm{yr}$ of the study period during the mid-July through $\mathrm{Au}-$ gust breeding season as presented in Table 2. In general, these figures depict well the tropical-like conditions during breeding. In 5 of the $9 \mathrm{yr}$ of the study period from mid-July through August there was an increasing trend $(P<0.05)$ for maximum daily temperatures (a significant decreasing trend occurred in only $1 \mathrm{yr}$ ) and a decreasing trend $(P<0.05)$ for $10-\mathrm{s}$ maximum wind gusts (a

Table 1. Least-squares breed means and direct and maternal breed additive and heterosis effects that genetically characterize the composite-bred population for birth and weaning weights and preweaning gains from MTDFREML ${ }^{1,2}$

\begin{tabular}{|c|c|c|c|c|c|}
\hline \multirow[b]{2}{*}{ Item } & \multirow[b]{2}{*}{ Overall $^{3}$} & \multicolumn{3}{|c|}{ Foundation breed } & \multirow[b]{2}{*}{ Pooled SED } \\
\hline & & Red Angus & Senepol & Tuli & \\
\hline Birth wt mean, kg & 35.5 & 33.9 & 37.8 & 34.7 & \\
\hline Direct breed & & -1.29 & 5.00 & -3.71 & 4.14 \\
\hline Maternal breed & & $-0.26^{\mathrm{ab}}$ & $-2.66^{b}$ & $2.92^{\mathrm{a}}$ & 2.59 \\
\hline Direct heterosis & $1.09(3.1)$ & & & & \\
\hline Maternal heterosis & $0.56(1.6)$ & & & & \\
\hline Weaning wt mean, kg & 261.4 & 251.5 & 257.3 & 275.5 & \\
\hline Direct breed & & 4.3 & -15.7 & 11.4 & 32.1 \\
\hline Maternal breed & & -14.2 & 11.6 & 2.7 & 19.9 \\
\hline Total maternal (1/2 direct + maternal $)$ & & -12.1 & 3.7 & 8.4 & \\
\hline Direct heterosis & $32.7(12.5)$ & & & & \\
\hline Maternal heterosis & $3.7(1.4)$ & & & & \\
\hline Preweaning ADG mean, kg/d & 1.10 & 1.133 & 1.017 & 1.158 & \\
\hline Direct breed & & 0.051 & -0.141 & 0.091 & 0.17 \\
\hline Maternal breed & & -0.020 & 0.056 & -0.035 & 0.08 \\
\hline Direct heterosis & $0.074(6.7)$ & & & & \\
\hline
\end{tabular}

${ }^{\mathrm{a}, \mathrm{b}}$ Partial direct or maternal breed regression coefficients bearing different superscripts within rows differ $(P<0.05)$.

${ }^{1}$ MTDFREML employed a full animal model to account for genetic relationships; however, the program does not provide SEM for fixed effects (including heterosis estimates), although SE of the difference (SED) can be obtained from use of linear contrasts. The above SED are the average of the SED obtained by making all pair-wise breed contrast comparisons from 3 separate analyses. Refer to the text for further details.

${ }^{2} \mathrm{An}$ estimate of maternal heterosis for preweaning gains could not be obtained.

${ }^{3}$ Values in parentheses are percentages. 
Table 2. Annual weather statistics during breeding season (mid-July through August) ${ }^{1}$

\begin{tabular}{cccccc} 
Year & $\begin{array}{c}\text { Maximum } \\
\text { temperature, }{ }^{\circ} \mathbf{C}\end{array}$ & $\begin{array}{c}\text { Avg. temperature, } \\
{ }^{\circ} \mathbf{C}\end{array}$ & $\begin{array}{c}\text { Maximum } \\
\text { humidity, } \%\end{array}$ & $\begin{array}{c}\text { Avg. humidity, } \\
\%\end{array}$ & $\begin{array}{c}\text { Wind, } \\
\mathbf{k m} / \mathbf{h}\end{array}$ \\
\hline 2007 & 36.1 & 28.0 & 100 & 81.7 & 10.0 \\
2008 & 36.7 & 28.4 & 100 & 77.5 & 13.8 \\
2009 & 40.0 & 30.5 & 97 & 67.1 & 16.6 \\
2010 & 41.1 & 30.7 & 94 & 71.1 & 9.8 \\
2011 & 42.8 & 30.5 & 100 & 72.7 & 15.9 \\
2012 & 41.7 & 30.4 & 100 & 68.6 & 14.6 \\
2013 & 41.7 & 30.1 & 100 & 74.2 & 13.2 \\
2014 & 38.9 & 30.4 & 100 & 75.6 & 15.3 \\
2015 & 38.9 & 29.9 & 100 & 78.9 & 13.4 \\
\hline
\end{tabular}

1Source: https://www.wunderground.com/.

${ }^{2}$ Value is the mean of daily sustained 10 -s maximum wind gust records for the breeding season.

significant increasing trend occurred in only $2 \mathrm{yr}$ ), and in 5 of the $9 \mathrm{yr}$ there was a decreasing trend $(P<0.05)$ for maximum humidity levels (a significant increasing trend occurred in only $1 \mathrm{yr}$ ).

Chi-square analyses revealed that sex ratio was consistent $(P=0.917)$ across years (2008 through 2016). Therefore, because the effects of year and sex could be considered to be independent, the next hypothesis test conducted involved the observed frequency of bull calves $(0.595 \pm 0.031)$ compared with the a priori probability of $P=0.5$, involving a one-sided test employing Chi-square (corrected for continuity). Observed numbers of bull and heifer calves born from 2008 to 2016 are shown in Table 3 . Results yielded a Chi-square value of $8.766(P<0.01)$, which provides evidence that proportionately more bull than heifer calves were born than expected. Although these results show that there were almost $50 \%$ more bull than heifer calves born, caution is warranted considering the lower bounds of the $95 \%$ confidence limits of the estimated population proportion of bull calves: 0.533 and 0.658. Of course, the causative mechanism needs to be elucidated, requiring further research.

To address the possibility that the distortion of sex ratio was not genetic but rather triggered by some environmental phenomenon, a supplemental analysis was performed involving sex records of fall-born calves $(\mathrm{n}=34)$ when a small fall calving herd of related animals was maintained over 4 yr during the same study period. Because of the small sample size in individual years, data were collapsed into sex classes. Chi-square results revealed interaction $(P$ $=0.0057$ ) between season of breeding (winter vs. summer) and sex class. From a separate analysis, the proportion of bull versus heifer calves from winter matings supported the hypothesis of an equal sex ratio. Overall, these results suggest that season rather than genetics was the basis for the disproportionate sex ratio.

It is well documented that in some species of birds and reptiles that a sex-reversal phenomenon occurs wherein at hot temperatures more male offspring are produced, whereas more female offspring are produced at temperatures less than $30^{\circ} \mathrm{C}$. An excellent review paper on this subject in reptiles was reported by Sarre et al. (2004) in which genetic- and temperature-sex determining mechanisms were examined. However, mammals are able to regulate body temperatures via homeostatic measures, including during pregnancy. Another temperature-driven mechanism is that embryonic development in females is accelerated due to higher temperatures that activate critical genes, which turns them into males as reported by Whitfield (2003). Such animals would be genetic females because they do not possess a Y-chromosome, which would be easy to confirm from a cytological analysis. To date, no known case of this event occurring in bovine has been reported.

In addition, the timing of AI in the bovine as related to ovulation, and relative to the physiological capacity or lifespan of $\mathrm{Y}$ and $\mathrm{X}$ sperm cells, has also been thought to

Table 3. Distribution of bull and heifer calves by birth year and test of significance ${ }^{1}$

\begin{tabular}{ccccc} 
Year & No. of bulls & $\%$ & No. of heifers & $\%$ \\
\hline 2008 & 12 & 63.2 & 7 & 36.8 \\
2009 & 12 & 60.0 & 8 & 40.0 \\
2010 & 11 & 68.8 & 5 & 31.3 \\
2011 & 21 & 58.3 & 15 & 41.7 \\
2012 & 22 & 55.0 & 18 & 45.0 \\
2013 & 17 & 56.7 & 13 & 43.3 \\
2014 & 13 & 50.0 & 13 & 50.0 \\
2015 & 22 & 68.8 & 10 & 31.3 \\
2016 & 20 & 60.6 & 13 & 39.4 \\
Total & 150 & 59.5 & 102 & 40.5 \\
\hline
\end{tabular}

${ }^{1}$ Chi-square test of a $1: 1$ sex ratio (pooled across years) yielded a value of $8.766(P=0.0015)$. 
influence sex outcome. However, results of such studies have not been conclusive (Rorie et al., 1999). Zobel et al. (2011) demonstrated that the site of semen deposition involving AI of dairy cows did affect sex ratio; $23 \%$ more bull calves resulted from AI into the uterine body as opposed to deep into the uterine horns. In the present study, only 12 AI were performed (all into the uterine body) over 3 yr that resulted in 7 bull and 5 heifer calves. Therefore, data from AI had little effect on the general sex ratio analysis. Eliminating records from AI changed, albeit slightly, the proportion of bull calves from 0.595 to 0.594 for natural matings. These results infer that the disproportionate sex ratio involved the outcome of natural matings.

One longstanding and seemingly more plausible theory is that lighter Y-chromosome-bearing sperm cells swim faster than X-chromosome-bearing sperm cells; however, the present consensus is that this theory is a myth according to the recent application of computer assisted sperm analysis (Grant, 2006), although differences in motility have been reported (Penfold et al., 1998). Nevertheless, the author is not aware of any reports that compare fertilizing ability of $\mathrm{Y}$ and $\mathrm{X}$ spermatozoa at higher temperatures, at least not involving bovine. Possibly an alternate mechanism exists in which $\mathrm{Y}$ versus $\mathrm{X}$ spermatozoa are more active at higher temperatures with respect to fertilization ability, ultimately resulting in more bull calves at birth. Of course, further research investigations are needed to test this proposed hypothesis. Across years at least $90 \%$ of cows conceived during their first estrous cycle, so it is unlikely that the distortion in sex ratio was due to differences in survival between male and female embryos.

\section{IMPLICATIONS}

This investigation genetically characterized a novel 3-breed composite population of Red Angus, Senepol, and Tuli that consists of African-derived genetics used for heat tolerance and adaptation to drought, which addresses the challenge of global climate change. Examination of trend line plots for production traits (e.g., fertility and survival, and cow and land efficiency) can be applied by producers to assess aspects of adaptation, especially over years of drought. Advantages of the slick coat gene on weaning weight performance may depend, in part, on coat color; further research is warranted. Judiciously choosing crossbreeding parameter values can assist producers in selecting breeds and utilizing heterosis to optimize performance. Summer breeding appeared to have produced more males. This phenomenon could potentially benefit producers, both seedstock and commercial, because bulls and steers compared with heifers have higher economic value. This information can guide beef producers in designing effective breeding programs, especially in the context of global climate change.

\section{ACKNOWLEDGMENTS}

The author wishes to express his gratitude to John Metz of National Oceanic and Atmospheric Association, Lauren Hyde of International Genetic Solutions for her technical assistance in providing genetic parameters for comparative analyses, Rick Machen of the King Ranch Institute of Ranch Management, and Chad Chase Jr. and Larry Kuehn of the Roman L. Hruska US Meat Animal Research Center, USDA ARS, for their critical and helpful review of the original manuscript, and to ranch management for access to records.

\section{LITERATURE CITED}

Ault, T. R., J. S. Mankin, B. I. Cook, and J. E. Smerdon. 2016. Relative impacts of mitigation, temperature, and precipitation on 21stcentury megadrought risk in the American Southwest. Sci. Adv. 2: https://doi.org/10.1126/sciadv.1600873. http://advances.sciencemag .org/content/2/10/e1600873.full.

BIF (Beef Improvement Federation). 2010. Guideline for Uniform Beef Improvement Programs. 9th ed. BIF, Raleigh, NC. Accessed Sep. 26, 2016. http://beefimprovement.org/library-2/bif-guidelines.

Boldman, K. G., L. A. Kriese, L. D. Van Vleck, and S. D. Kachman. 1993. A Manual for Use of MTDFREML. A set of programs to obtain estimates of variance and covariances. USDA, ARS. Accessed Sep. 26, 2016. https://aipl.arsusda.gov/software/mtdfreml/.

Bonsma, J. C. 1949. Breeding cattle for increased adaptability to tropical and subtropical environments. J. Agric. Sci. 39:204-219.

Bourdon, R. M. 2000. Understanding Animal Breeding. 2nd ed. Prentice-Hall Inc., Upper River Saddle, NJ.

Bryant, F. C. 2009. 2009 was interesting, to say the least. South Texas Wildlife. 13:4.

Capper, J. L. 2011. The environmental impact of beef production in the United States: 1977 compared with 2007. J. Anim. Sci. 89:4249 4261. https://doi.org/10.2527/jas.2010-3784.

Chase, C. C., Jr., T. A. Olson, A. C. Hammond, M. A. Menchaca, R. L. West, D. D. Johnson, and W. T. Butts. 1998. Preweaning growth traits for Senepol, Hereford, and reciprocal crossbred calves and feedlot performance and carcass characteristics of steers. J. Anim. Sci. $76: 2967-2975$.

Chase, C. C., Jr., D. G. Riley, T. A. Olson, S. W. Coleman, and A. C. Hammond. 2004. Maternal and reproductive performance of Brahman $\times$ Angus, Senepol $\times$ Angus, and Tuli $\times$ Angus cows in the subtropics. J. Anim. Sci. 82:2764-2772.

Davis, S. R., R. J. Spelman, and M. D. Littlejohn. 2017. Breeding and genetics symposium: Breeding heat tolerant dairy cattle: The case for introgression of the "slick" prolactin receptor variant into Bos taurus dairy breeds. J. Anim. Sci. 95:1788-1800. https://doi.org/10.2527/jas .2016.0956.

FAO. 2013. Tackling Climate Change Through Livestock: A Global Assessment of Emissions and Mitigation Opportunities. Food and Agriculture Organization of the United Nations, Rome, Italy. Accessed Sep. 26, 2016. http:// www.fao.org/3/i3437e.pdf.

Finch, V. A., L. L. Bennett, and C. R. Holmes. 1984. Coat colour in cattle: Effect on thermal balance, behavior and growth, and relationship with coat type. J. Agric. Sci. (Camb.) 102:141-147. 
Foster, L. A., P. J. Fourie, and F. W. C. Neser. 2009. Effect of heat stress on six beef breeds in the Zastron district: The significance of breed, coat colour and coat type. S. Afr. J. Anim. Sci. 39:224-228. https://doi.org/10.4314/sajas.v39i1.61180.

Franke, D. E., S. M. DeRouen, A. R. Williams, and W. E. Wyatt. 2005. Direct and maternal breed additive and heterosis genetic effects for reproductive, preweaning, and carcass traits. Pages 204-209 in Proc. Symp. Tropic. Adapt. Breeds, Am. Soc. Anim. Sci., Southern Sect. Meet. Am. Soc. Anim. Sci., Champaign, IL.

Grant, V. J. 2006. Entrenched misinformation about X and Y sperm. BMJ 332:916 https://doi.org/10.1136/bmj.332.7546.916-b.

Hammond, A. C., C. C. Chase Jr., E. J. Bowers, T. A. Olson, and R. D. Randel. 1998. Heat tolerance in Tuli-, Senepol-, and Brahman-sired $\mathrm{F}_{1}$ Angus heifers in Florida. J. Anim. Sci. 76:1568-1577.

Hammond, A. C., and T. A. Olson. 1994. Rectal temperature and grazing time in selected beef cattle breeds under tropical summer conditions in subtropical Florida. Trop. Agric. (St Augustine) 71:128 134 .

Hammond, A. C., T. A. Olson, C. C. Chase Jr., E. J. Bowers, R. D. Randel, C. N. Murphy, D. W. Vogt, and A. Tewolde. 1996. Heat tolerance in 2 tropically adapted Bos taurus breeds, Senepol and Romosinuano, compared with Brahman, Angus, and Hereford cattle in Florida. J. Anim. Sci. 74:295-303.

Hansen, P. J. 2013. Cellular and molecular basis of therapies to ameliorate effects of heat stress on embryonic development in cattle. Anim. Reprod. 10:322-333.

Herring, A. D., S. F. Cunningham, L. V. Cundiff, J. O. Sanders, C. C. Chase Jr., W. A. Phillips, J. F. Baker, J. W. Holloway, B. G. Warrington, and S. W. Coleman. 2005. Varying differences between sexes in birth weight and weaning weight of calves sired by tropically adapted breeds at six diverse U.S. locations. Pages 182-188 in Proc. Symp. Tropic. Adapt. Breeds, Am. Soc. Anim. Sci., Southern Sect. Meet. Am. Soc. Anim. Sci., Champaign, IL.

Holloway, J. W., B. G. Warrington, D. W. Forrest, and R. D. Randel. 2005. Lifetime performance and efficiency of $\mathrm{F}_{1}$ tropically adapted beef cattle breeds $\times$ Angus in semiarid rangeland. Pages 110-117 in Proc. Symp. Tropic. Adapt. Breeds, Am. Soc. Anim. Sci., Southern Sect. Meet. Am. Soc. Anim. Sci., Champaign, IL.

Littlejohn, M. D., K. M. Henty, K. Tiplady, T. Johnson, C. Harland, T. Lopdell, R. G. Sherlock, W. Li, S. D. Lukefahr, B. C. Shanks, D. J. Garrick, R. G. Snell, R. J. Spelman, and S. R. Davis. 2014. Functional reciprocal mutations of the prolactin signalling pathway define hairy and slick cattle. Nat. Commun. 5:5861 https://doi.org/10.1038/ ncomms6861.

Lukefahr, S. D. 2007. Invited paper: Coat colour genetics in the Tuli breed. So. African Stud Breeder 16:39-46.

Mader, T. L., S. M. Holt, G. L. Hahn, M. S. Davis, and D. E. Spiers. 2002. Feeding strategies for managing heat load in feedlot cattle. J. Anim. Sci. 80:2373-2382.

Nelson, G. C., M. W. Rosegrant, J. Koo, R. Robertson, T. Sulser, T. Zhu, C. Ringler, S. Msangi, A. Palazzo, M. Batka, M. Magalhaes, R. Valmonte-Santos, M. Ewing, and D. Lee. 2009. Climate Change: Impact on Agriculture and Costs of Adaptation. Int. Food Policy Res. Inst., Washington, DC.

Nielsen-Gammon, J. W. 2011. The changing climate of Texas. Pages 39-68 in The Impact of Global Warming on Texas. J. Schmandt, J. Clarkson, and G. R. North, ed. 2nd ed. Univ. Texas Press, Austin, TX.
NOAA (National Oceanic and Atmospheric Association). 2017. National Centers for Environmental Information. Accessed Mar. 13, 2017. https://www.ncdc.noaa.gov/cag/time-series/us/41/9/tavg/ all $/ 1 / 1950-2017$ ?base_prd=true\&firstbaseyear $=1901 \&$ lastbaseyear= 2000 .

Olson, T. A., C. Lucena, C. C. Chase Jr., and A. C. Hammond. 2003. Evidence of a major gene influencing hair length and heat tolerance in Bos taurus cattle. J. Anim. Sci. 81:80-90.

Ortega, J. A., S. D. Lukefahr, and F. C. Bryant. 2013. Optimum stocking rate, monitoring, and flexibility: Key components of successful grazing management programs. Rangelands 35:22-27.

Penfold, L. M., C. Holt, W. V. Holt, G. R. Welch, D. G. Cran, and L. A. Johnson. 1998. Comparative motility of X and Y chromosomebearing bovine sperm separated on the basis of DNA content by flow sorting. Mol. Reprod. Dev. 50:323-327.

Peters, K. J., P. Horst, and H. H. Kleinheisterkamp. 1982. The importance of coat colour and coat type as indicators of productive adaptability of beef cattle in a subtropical environment. Trop. Anim. Prod. 7:296-304.

Phillips, W. A., R. P. Wettemann, S. W. Coleman, and J. W. Holloway. 2005. Evaluation of Boran, Tuli, Gelbvieh, and Brahman $\mathrm{F}_{1}$ crosses in Oklahoma. Pages 160-165 in Proc. Symp. Tropic. Adapt. Breeds, Am. Soc. Anim. Sci., Southern Sect. Meet. Am. Soc. Anim. Sci., Champaign, IL.

RAAA (Red Angus Association of America). 2013. Breeder's Guide. RAAA, Denton, TX. Accessed Sep. 26, 2016. http://assets.redangus .org/media/Documents/Registration/Breeders_Guide/Appendix/BG _Appendix_1-3-13.pdf.

Rhoad, A. O. 1955. Breeding Beef Cattle for Unfavorable Environments. A. O. Rhoad, ed. Univ. Texas Press, Austin, TX.

Rorie, R. W., T. D. Lester, B. R. Lindsey, and R. W. McNew. 1999. Effect of timing of artificial insemination on gender ratio in beef cattle. Theriogenology 52:1035-1041.

Sarre, S. D., A. Georges, and A. Qiunn. 2004. The ends of a continuum: Genetic and temperature-dependent sex determination in reptiles. BioEssays 26:639-645.

Scasta, J. D., L. Henderson, and T. Smith. 2015. Drought effect on weaning weight and efficiency relative to cow size in semiarid rangeland. J. Anim. Sci. 93:5829-5839. https://doi.org/10.2527/jas.2015 -9172 .

Schmutz, S. M., and D. L. Dreger. 2013. Interaction of MC1R and PMEL alleles on solid coat colors in Highland cattle. Anim. Genet. 44:9-13. https://doi.org/10.1111/j.1365-2052.2012.02361.x.

USDA. 2016. Livestock Marketing Information Center. C-P-66. Sep. 2, 2016. USDA. Accessed Oct. 2, 2016. http://lmic.info/.

Weaber, R. L. 2015. Crossbreeding strategies: Including terminal and maternal crosses. Pages 117-130 in Proc. Range Beef Cow Symp. XXXIV, Loveland, CO. Univ. Nebraska, Lincoln.

Whitfield, J. 2003. Testicles may be on the outside in the interests of equality. Nature https://doi.org/10.1038/news030421-10.

Zobel, R., D. Geres, I. Pipal, V. Buic, D. Gracner, and S. Tkalcic. 2011. Influence of the semen deposition site on the calves' sex ratio in Simmental dairy cattle. Reprod. Domest. Anim. 46:595-601. https:// doi.org/10.1111/j.1439-0531.2010.01708.x. 